\title{
Liturgy as an anti-racist praxis for Reformed Churches in South Africa
}

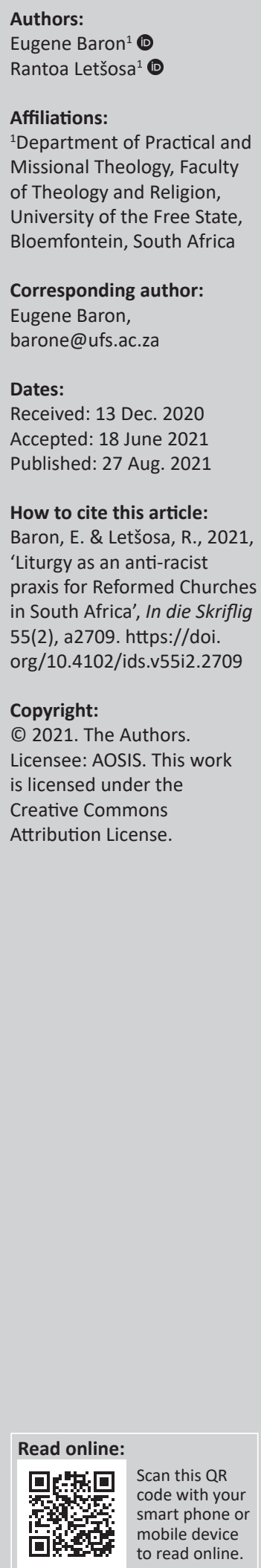

\begin{abstract}
The sin of racism severely and deeply affects the victims. The response in many instances is to remain silent to survive. The result is traumatic and even becomes symptomatic unless addressed. This article discussed the role that liturgy could play as an anti-racist praxis. However, firstly is discussed the underlying struggle of two Reformed Churches to become not only in polity but in praxis, non-racial through the liturgy as an anti-racism praxis. Liturgy is defined in the article not only as referring to the liturgical elements of a worship service, but also within its broader sense as the covenant people's actions when they meet, listen to, worship and glorify the triune God within all contexts. This is also true when they mutually meet each other for edification. The authors focused partly on some liturgical elements in the worship service; however, the broader context - referring to the liturgy of life - received serious attention.
\end{abstract}

Contribution: The article holds that liturgy within the church service context, but mainly with what happens outside in life, would play a crucial role in helping Christians become antiracist. The article follows a discourse analysis on the journey of two reformed denominations, on how they could, through the liturgy of life, establish an anti-racist praxis.

Keywords: racism; anti-racism; reformed; liturgy; theology.

\section{Introduction}

In 2020 the \#BlackLivesMatter movement mobilised various Americans to actively engage the issues of racism in the United States of America (USA) in the wake of the death of an African American, George Floyd. During the protests, the picture of the former president of the United States of America, Donald Trump, went viral on social media depicting him before a church building, lifting the Christian Bible in defiance amidst the prevalent anti-racism protests of millions of black and white Americans. This brought to the fore the intricate relationship between church and anti-racism. Though the gesture of Donald Trump was sternly critiqued for using the church to endorse his rejection of the anti-racism protest at the time, the authors found it necessary to ask the question about how the church, in contrast to the Trump gesture, can become actively involved in an anti-racist praxis. The deliberate employment of an anti-racist praxis in congregations, indicates the authors' view that there is a consistent interaction between practices and theory functioning in the church that perpetuate systemic racism. It is in this sense that liturgy becomes an essential tool in shaping the praxis of congregations, to either uproot racist praxis, or as Trump did, to be apathetic and lethargic to join the cause of various anti-racism movements globally.

South Africans have shown solidarity with the \#BlackLivesMatter movement on various fronts, affirming their racist context in the aftermath of apartheid. This confirms that the systemic nature of racism is still alive in society and the church. It remains a question whether these acts of anti-racism and solidarity with those that are racially oppressed in congregations, are also promoted, embodied, and expressed within the Liturgy of Reformed Churches in South Africa. The further question is to what extent has it taken shape and form in these churches - that have, during apartheid, supported actively or passively the apartheid policies. ${ }^{1}$

Furthermore, it should be noted that the Reformed Churches in South Africa have been contributing, at least since the dawn of democracy, in their own way to the 'breaking-down' of

\footnotetext{
1.James Buys delivered the response of the Uniting Reformed Church to the Truth and Reconciliation Commission of South Africa, in which he lamented the actions of the former black congregations (Dutch Reformed Church in Southern Africa \& Dutch Reformed Mission Church). He argues, they did not do enough to address the devasting effects of the racist ideology of apartheid. This response was lauded by the then chairperson of the Commission. He found it astonishing that a black church would also find that their strategies in breaking the by the then chairperson of the Commission. He found it astonishing that a black church would also find that their strategies in breaking the
racial barriers down, were not sufficient. In this regard, an example could be seen in the establishment of a convent between the URCSA racial barriers down, were not sufficient. In this regard, an example could be seen in the establishment of a convent between the URCSA
Wynberg (a coloured congregation) and DRC Wynberg (a church with white congregants). This was an extraordinary relationship, and indeed a miracle, that was never seen within the Reformed Church in South Africa since apartheid. However, the joint congregation unfortunately did not last long: after the death of the URCSA, Wynberg minister, James Buys, it also ended.
} 
walls of racial separation. They have made attempts to break barriers of racism and segregation. This has, in some cases, taken the form of amalgamations, agreements between racially-based churches towards greater cooperation, et cetera. ${ }^{2}$ Yet, with all these efforts, one may still ask the following question: When will the time come that we practise the new song referred to in Revelations 5:9?:

... and they sang a new song: You are worthy to take the scroll and open its seals, because you were slaughtered, and you purchased people for God by your blood from every tribe and language and people and nation.

Strickland (2020) refers to this as a glimpse into our future as Christians, as unified, we worship God in Christ.

The article commences with discussing the need for addressing anti-racism in the church after the dawn of democracy in South Africa. Two denominations have undergone unification: the Uniting Reformed Church in Southern Africa (URCSA) (a merger between the then Dutch Reformed Mission Church [DRMC] with the Dutch Reformed Church in Africa [DRCA]), and an assessment will also be given on the road travelled towards racial reconciliation in the Reformed Churches in South Africa (henceforth GKSA), especially the merging of the churches in the Synods GKSA and Midlands. In the part on URCSA we shall reflect on what happened after the unification in 1994. In the part on the GKSA is discussed the unification process, especially from the perspective of the churches in the then Synod Midlands and subsequently in the newly merged National Synod of the GKSA. Secondly, it discusses the views of Kujawa-Holbrook, who has developed a theory around the challenges of racism in the church in the American context. This will then serve as a normative framework in which the authors would discuss the challenge of racism in the Reformed Churches in South Africa. It is also the approach in this article that liturgy can positively combat racism in churches within the reformed tradition.

\section{Racism and anti-racism}

During the colonial period, European ideas about race developed from seeing it as a matter of origin or lineage to divide human beings into racial types in an attempt to discern genetic markers of race (Banton 1998). The result is personal prejudice and racialisation, systematic discrimination based on individual physical traits, of which skin (Carter 2008; Jennings 2010) is the most prominent. So, although race may be imaginary, it is experienced physically. The flip side of modern racism is white supremacy, which is integral to it. Racism was endemic to European colonialism and imperialism, especially in Africa. In other words, it was the ordinary experience of people of colour (Young 1994). Biko (1978:25) describes racism as the 'discrimination by a group against another for subjugation or maintaining subjugation'.

2.See a lengthy discussion on this amalgamation of the URCSA in the forthcoming book by Baron and Botha (2020) Obedience and servant leadership: Apollis, Appies, Buti, Buys.
This description means that racism has indeed a raciallybased 'power' element, that is still prevalent in relationships in South Africa. Because racism is systemic, it can only be rooted out by active anti-racism. Racism is not only within societal structures, but also in church structures.

Loubser (1987:7) refers particularly to the Dutch Reformed Church (DRC) council of the Drakenstein Congregation in 1703 , that refer to 'Ham' as a biblical reference to those people who are to be known as 'servants of servants'. Spangenberg (2019) showcases the way the Bible was used to endorse racism through justifying an inferior race through the connotation of 'Ham' - assuming that his descendants were those that had dark skin, as slaves had darker skin, hence, they were the cursed ones in Genesis 9:25. However, Spangenberg states (2019):

... there is no reason for this assumption in the biblical text, but we know from the rest of the Old Testament that Israelites were instructed to subdue and even to exterminate the Canaanites. During the apartheid era, because of this biblical interpretation, many whites viewed all dark-skinned people as descendants of Ham and Canaan. (p. 1)

\section{A root cause for racism and the positive role of reformed liturgy}

In the context of this article, liturgy will be defined as both what a community of worship does before God in public assemblies, and the interaction of the members with one another, whether outside of the worship service or in the worship service (Becera 2016). This is the liturgy of life that goes beyond only the elements of liturgy in a worship service. $^{3}$ In both the liturgy of life and liturgical elements like the Eucharist, members of congregations were also introduced to the idea that some races are inferior to others. Hence their exclusion from the Eucharist because of the racial prejudices of some white DRC members in the Cape during the 1800s.

The DRC argued at the time that the decision to separate the black members from the white members, was because of the 'weaknesses of some', and ratified this to become part of its polity and subsequently led to years of racial separation. In essence, what transpired between the white and black congregations in South Africa, were more than only racial prejudices, but racial discrimination. Therefore, there is a need for anti-racism. The authors argue that there is a need to 'liberate' reformed liturgy from its 'symbolic' but also in other instances, the continuous perpetuation of racism in the liturgy of Reformed Churches.

In recent academic contributions, especially that of Kritzinger (2020), he argues that the Eucharist can become a symbol of inclusion for those that, in the reformed tradition, has come

3.See especially the work of Ricky Manalo in his book. The liturgy of life: The interrelationship of Sunday Eucharist and everyday worship practices, in which he interrelationship of sunday Eucky ist and everyday worship practices, in which he uses the idea of the 'Liturgy of life' to show how it 'examines the interrelationship between the practice of Sunday Eucharist and the many nonofficial worship practices that mark the everyday lives of Christians, who continually negotiate the boundaries of official teaching on liturgy'. 
to understand it as a place of separation between white and black people. This is also the authors' purpose - to argue that the reformed liturgy can play such a role. Therefore, not to ponder extensively on the root causes of racism in the Reformed Church, it would be critical for the authors to reflect succinctly on the current developments and progress. They will also look into some solutions to uproot racism and embark on an anti-racist praxis within reformed congregations in South Africa. Though there are various approaches and suggestions in this regard, the authors limit their reading to Kujawa-Holbrook as a theoretical framework to assess and critically discuss the anti-racism journey in the Reformed Churches in South Africa. Subsequently, the authors provide some proposals on how the liturgy could be used to address racism.

\section{Kujawa-Holbrook on church and racism}

Kujawa-Holbrook discusses challenges, which are also translatable into the South African context. But for the purpose of this article, we ask how we can move from a racist congregation, or as in URCSA's case, not only a non-racial church in polity but a move towards denominations that embraces an anti-racist praxis. In this regard, KujawaHolbrook (2006) assists when she argues that amidst the challenges of a declining church and the context of a multi-cultural society, and as Desmond Tutu would refer to post-apartheid South African society as a 'rainbow nation', the church needs to break the barriers of the oftenreinforced homogeneity and focus more on promoting multiculturalism and advocating social change. To understand the complexity of this problem and dealing with its impact, Kujawa-Holbrook suggested stages (or categories) of change that characterise congregations on their pilgrimage to transformational communities.

The first stage concerns the entire congregation perpetuating domination of one racial group above the other. There is segregation on all levels of decision making in such a congregation, when one racial group perceives other races as inferior.

The second stage (or category) is the passive congregation with the privilege of holding power in the church. There are a few people of colour, but they uphold the status quo and do not threaten any established order. They behave like a club with limited access to those who might change or influence the majority's cultural forms, history, worship language or history.

The third is the compliant congregation. They place the burden of change on the marginalised group. They avoid conflict, and they expect that those who come to join, may do so on the condition that they assimilate. Church facilities are shared, there is occasional participation in joint worship services with a shared desire for more cross-cultural relationships - but there is no sharing in the power and ownership of the church. Racism, or the discussion of it, is suppressed for the sake of artificial unity, which is only visible during the congregational gathering.

The fourth is the anti-racist congregation - this congregation has crossed racial barriers of white supremacy and racism. They develop relationships with other races and commit to eliminate racism in the congregation. The problem is that this kind of congregation's institutional structures continues to maintain white privilege and white culture.

The fifth is a redefining congregation, and according to KujawaHolbrook goes through five stages of recognition and acknowledgement: (1) racism is inherent in all institutions, (2) racism is instrumental in both historic and current institutional contexts, (3) there is a need for a commitment to change, (4) mechanisms must be in place to facilitate change, and (5) in the process of change there must be action. It is acknowledged in this congregation that education and training that focuses on anti-racism, is paramount to allow a multi-racial community. A regular audit is essential in these congregations in all institutional life aspects, ensuring full participation of people of colour. They are also intentionally accountable to communities of colour, hence the organisation of structures, policies and practices that should to be such that they distribute power among all diverse racial groups.

The sixth type of congregation mentioned here, is the transformed congregation that upholds a future vision of a new reality. It is thoroughly multi-cultural and has overcome systemic racism and all other hidden forms of racism. In this congregation, the search for a unique and surprising spirituality where all strive for meaning and wholeness together, is present. In this congregation, those in power fight to correct the existing deep power imbalances. The perpetuation of part of one human community takes place, and everyone benefits. In the next section, we reflect on the journey of two Reformed Churches in South Africa and how far they have travelled in terms of racism, and whether there is a need for an anti-racism strategy.

\section{Racism and anti-racism in two denominations in the Reformed tradition}

In the first instance, the authors reflect on the URCSA after the amalgamation of the churches reserved for coloured people (DRMC) and the church for Africans (DRMC). The URCSA embarked on such a process of internal unity in 1994 and subsequent synods (cf. Baron \& Botha 2020). Secondly, the authors reflect on the road of anti-racism in the Reformed Churches in South Africa, and in the Afrikaans Gereformeerde Kerke in Suid Afrika (GKSA), henceforth RCSA. The Reformed Church in Southern Africa is a merging of the churches of the Synods of the previous GKSA, which was primarily for white people and the churches of the last Synod Midlands, which consisted primarily of black people. 


\section{The Uniting Reformed Church in Southern Africa and racism}

In this section, the focus would be on URCSA's initial history to become non-racial, its subsequent General Synod (GS) decisions after its establishment in 1994, then some academic reflections from URCSA academics in terms of the challenges of racism and internal unity in the church. The church comprises mainly coloured and black people in terms of the apartheid racial classification.

In the journey towards unification, there were issues raised on racism, and especially the references made to 'internal unity' within the URCSA. For instance Die Ligdraer, during 1990-1994, reports that during the unification talks of the DRMC and the DRCA, there were slurs of racism thrown to and from between executive members of the church. Here the issue seems to have been an underlying issue of racism (Baron 2020:33). Kritzinger (2020:11) refers to some GS decisions and discussions on internal unity and racism since 2008. One of the decisions was to clarify the goal of URCSA on internal unity, which was to '... help African and Coloured members to embark on a guided process to deal with their racialised cultural identities and negotiate new relationships to build unity in the church'. However, during the subsequent synod, the members also lamented that the resolution taken by the General Synod in 2008 has not yet come to fruition. However, the goal still pursued and is taken up by the church through its strategic plan. The issue of 'racism' was squarely placed onto the table as an issue that still needs to be addressed in its strategic plan of 2014-2024.

In the URCSA's strategic plan 2014-2024, one of the objectives is to: 'Constructively address racism in church and society through academic, theological and other programs'. Moreover, in the same document, the expected outcomes are stated as follows:

- Improves relations between different racial and cultural groups in the URCSA

- Internal church unity, multi- and trans culturalism would be effectively addressed [sic] in the URCSA

- Will enhance the transformation of the URCSA to a truly transcultural church in a reformed African context

- Will strengthen the establishment of transcultural congregations in the URCSA

The strategic plan and URCSA GS' decisions show that racism is not an issue of the past, and should therefore be dealt with. Furthermore, URCSA academics also reflected on racism challenges in the church. Consequently, the authors would reflect on the developments in this regard through focusing on the recent publications in celebration of its 25th year of existence, that was subsequently published as a unique collection in 2019 by the journal Studia Historiae Ecclessiastiae. In an analysis of the academic contributions, one could identify a considerable emphasis on the oppressive institutional nature in the church (URCSA), which academics and theologians underscored, for instance the perpetuation of gender insensitivity (Nel 2019), gender inequality (Plaatjies Van Huffel 2019), as well as other forms of oppression (racial, womanist, etc.) that were lamented and necessitated a further endeavour for working towards liberation.

Nevertheless, the challenge of 'internal unity' raised by the late Plaatjies Van Huffel (2019), and her ordeal at the Cape Synod meeting in 2018, became a thorny issue on the first day of the conference. Though none of the conference speakers directly addressed the issue of race or racism through its articulations, this was indeed alluded to or implicitly part of the reflection on 'internal unity', as could be seen above. For instance, Baron (2019) argued that the challenge to develop a 'missional consciousness' was the result of our racial history, in which the church, as the amalgamation of two former 'mission churches', still struggle to escape from. Even though the church, by adoption of the Belhar Confession, had rejected oppression, racial domination and apartheid, it should lament the continued oppression in all its forms in the URCSA through the stifling agencies of different members in the church. For Baron (2020), the omission to address the 'mission church' syndrome, often results in 'internal' racism. This occurs when racial oppression has become so internalised by the oppressed, that they perpetuate such praxis even in the absence of the former white oppressors. This leads to systematic racism within the new church. Biko (1978) and Fanon $(1963 ; 1967)$ articulate this as the psychological effects on the oppressed in a post-colonial context like South Africa. Baron (2019) argues that this is not different in church contexts, that although pigmentocracy becomes the the essential point on the agenda in most churches seeking to unburden themselves from racial supremacy, internalised racism is not being dealt with, and therefore his proposal for a 'missional consciousness' (Baron 2020).

The contribution of Plaatjies Van Huffel places the struggle for 'internal unity' squarely onto the table, amidst many celebratory aspects of the URCSA since its establishment in 1994. Since the inception of the URCSA (1994), the first moderator Nick Apollis has also articulated in his first moderator's address to the first Synod of the URCSA in Bloemfontein (1998), that internal unity would be a key concern in the future of the URCSA (URCSA 1997, cf. Baron \& Botha 2020). Though the unification with the white congregation (DRC) remained a priority, Baron (2020) attests that internal unity has been an issue even in the initial stages of the unification, and has since then not received proper lamenting and action.

There are various signals that the URCSA has made continuous efforts. Die Ligdraer (the former DRMC newspaper) was renamed and subsequently also its content. A dual-medium communication (Afrikaans and English) in the church's newspaper was changed to a fully fledged English version, which became a new mode of communication among all members in the URCSA News. ${ }^{4}$ Then, during the worship service to celebrate the 25th year of the URCSA, a 4.This is currently the name of the newspaper of the URCSA. 
multi-lingual hymn book was launched, and the liturgy during the service was also done in different African languages to accommodate all.

Nevertheless, another issue which concerns the 'internal unity', is the composition of the moderature in the Cape Synod of URCSA. The Cape Synod introduced the infamous $50 / 50$ principle during their first official meeting, and decided then that the election and representation of moderature members should be based on 50\% Xhosaspeaking members (mainly African) and 50\% Afrikaansspeaking members (mainly coloured). Whether this was adequate or relieved the racial tensions, could be seen in the recent contentious debate of the Cape Synod in 2018, which showcased that those racial tensions were not an issue of the past. This led also to the resignation of Plaatjies Van Huffel, or lamented the challenge of internal unity.

Tshaka and Maruping (2010) had referred a decade earlier to cases where coloured congregations would call coloured ministers of the Word, and African congregations would call African Ministers of the Word. They also lamented that congregations of the URCSA still functioned within their own geopolitical and racial comfort zones, as created by the apartheid government. Not a lot of pulpit exchanges happened between coloured and African ministers and the demographics of congregations. Most of the members would become a member of a congregation representing their own racial group. What is noteworthy, however, is that there had been a number of pulpit exchanges, and that white DRC congregations participated. Taking Tshaka and Maruping's critical reflection into account 15 years before the 25th celebration in 2019, it is evident that the status quo continues to exist. Not much has been done to ensure the establishment of mixed-race congregations.

The URCSA indeed continually made attempts to become in polity and praxis a non-racial church. The former Moderator of the URCSA, Rev. James Buys, the local minister at URCSA Wynberg, established, for example a joint agreement with the DRC Wynberg and functioned as one church, which was the first of its kind in the URCSA (Baron \& Botha 2020). Sadly, this joint relationship between the URCSA Wynberg, and the white congregation DRC Wynberg, was abolished. There remains a need to reflect on the sustainability of not only established mixed-race congregations, but more intensively on racism, and antiracist strategies. This, alongside other factors that might contribute to the unsustainability of such efforts and initiatives already mentioned.

However, in interviews with some of his (James Buys) African colleagues, they made no secret that they were 'brothers and sisters' and that moving towards a fullyfledged cultural sensitivity and a non-racial church, was a priority, especially since Buys' tenure (Baron \& Botha 2020). James Buys was always concerned about their (African ministers and congregations') financial welfare while also showing sensitivity towards their culture (Mbenenge 2020). ${ }^{5}$

It is also evident that the URCSA itself has not been sufficiently articulating 'internal unity' as a 'race' issue, but rather in terms of ethnic and cultural differences. These are not lesser important, but made the issue of racism something to be placed on the back burner. However, though cultural identities are equally important, articulating the issue as racism is also important, since most cultural identities had been racialised during apartheid. The historic separate development policies have not only led to prejudices, but also to small-scale discriminations between these groups. Therefore it begs the following question: Would the identification of 'internal unity' as a race problem, not be crucial in crushing the head of the serpent? Bulmer and Solomon (1999:245) argue that often racism could be escaped by not referring to racism, but to use other euphemisms instead. They (Bulmer \& Solomon 1999) state:

We must be prepared to focus unsentimentally on anti-racism's inability to respond to other distinctive aspects of these new forms of racism. Apart from the way that racial meanings are inferred rather than stated openly, these new forms are distinguished by the extent to which they identify race with the terms culture and identity, terms which have their own resonance in anti-racist orthodoxy. (p. 245)

Kujawa-Holbrook (2006:50) also insists in assessing the journey towards non-racialism in URCSA. She mentions that anti-racism should not be a project or a church programme, but part of the lifeblood of being God's witnesses in the world. We should note that both the Cape Synod and other synods adopted the vision of becoming missional churches. In these discussions, it is evident that the church should be God's witness in the world. Still, little time has been spent on transforming or addressing the internal racial character of the URCSA congregations to ensure cross-racial and crosscultural projects. These general discussions have often become a scapegoat and fail to address the elephant in the room (racism). There are less racially integrated congregations in the URCSA among coloured and black people. Less than five percent of such racially mixed congregations (KujawaHolbrook 2006:46) exist, and this is mainly attributed to reasons such as language challenges. At the same time, this has not been a challenge to the same people that their employers have been forced to work together as colleagues, and that language was not a significant impediment then. Workplaces in South Africa has already gone beyond such an argument - using English as the preferred language of communication, while the prospects to move towards a multi-lingual context is on the horizon. Why then does this still prevent the church, which has in principle become a nonracial church, from crossing barriers?

However, the role of the Belhar Confession, not only as an element of liturgy in a worship service, but as part of a 'liturgy of life', should not be underestimated. This has made 5.Interview held with Rev Mibenenge, August 2020. 
the church members confess any sin of racial discrimination publicly. However, as crucial as this confession is in the church, the frequency of such a confession being used in the URCSA congregations, compared to other confessions of faith, is still worrying, since the above brief analysis shows that there is still much-needed attention to be given to the matter, and that it should be more than an element of the liturgy in a worship service. As argued in this article, it should become part of a praxis - 'Liturgy of Life'.

Confessions of faith on the congregational level, should not become more of a recitation during worship services rather than instilling a deeper understanding of the implications and embodiment thereof. This is also a challenge that must be addressed liturgically. It should be noted that confessions of faith by their very nature lead to unification rather than to division. Therefore, as would be argued at the end of this article, liturgy would be able to fill a role in addressing racism. However, it should be noted that the Belhar Confession is an important instrument to place racial discrimination continually and squarely on the table during worship services in the URCSA (as Holbrook also suggests in her phases for moving towards a non-racial congregation). Holbrook's argument is that there should be 'education' and 'training' moments to rid churches from racism, as an act of racism. Therefore, the liturgist should see the Belhar Confession as a learning, educational moment for the congregation. The Belhar Confession becomes alive, as is the reality of racism within church structures and societal structures at large.

\section{Reformed Church in South Africa and racism}

In this section, the authors focus on the Reformed Church in South Africa (RCSA), ${ }^{6}$ particularly on the synod meetings of the congregations within the Synod Midlands since 20042008, when deliberations about merging the three different Synods of the Reformed Churches in South Africa commenced. One of the authors was part of all these four synodical meetings, and actively involved in the debates. In the very first synodical meeting, one of the authors was part of the moderature and hence gives first-hand information. By way of introduction to the problem, issues pertaining to the spirituality of black people in the Reformed Churches encountered negligence and have been undermined (Baloyi 2016:3). Certain matters, like witchcraft, poverty and the healing ministry, including the ordination of women in office, especially contextual issues in which men leave rural areas for the city and women have to remain behind and play leadership roles, are matters that do not receive enough attention even in Synodical meetings. Baloyi (2016:3) opines that the financial dependency syndrome gave rise to the colonisation of the mind of the black people in the Reformed Churches. They cannot speak for themselves because the one with the gold makes the rules, in this case, determined the agenda.

6.In this section 'Reformed Churches in South Africa' would mean "Gereformeerde Kerke in Suid Afrika' (GKSA).
During the Synod of Midlands' meeting of the Reformed Churches (comprising mainly black people) held in January 2004 in Potchefstroom, Dr C.J. Smit brought greetings from the then Synod GKSA primarily of white people. In his statement, he emphasised mainly the unity of the churches. These words came directly from his response:

It is now the time that the Synods of Reformed Churches in South Africa unite. Synod GKSA is ready for church unity. This is the time that Reformed Churches should make a turning point in history, no more division between Synods because of race.

During the opening of the second day in a subsequent synodical meeting of Synod Midlands in November 2006, Dr V.J. Fatuse reminded the meeting that transformation is a process that must be approached with open minds. Still, in the same breath, he encourages unity among the three synods, as this was long overdue. During the same meeting, Prof. F. Janse van Rensburg in bringing greetings from the Theological Seminary of Potchefstroom, reflected on unity with the Synod Midlands in a different structural way. He emphasised that there was virtually no difference of opinion with the GKSA Potchefstroom. He thanked the Synod for the positive attitude already expressed in the decision during Synod 2004 to proceed with the restructuring. In his conclusive words, he envisaged: 'We trust that 2007 will see the first geographical classes, 2008 the first geographical regional synods, and in 2009 the first new General Synod'.

Unfortunately, Prof. Janse van Rensburg's wish did not realise immediately after the Synod Midlands meeting held in August 2008. Only during this seating did the Midlands Synod resolve not to meet again as Synod Midlands but rather participate fully in the new geographical classes, regional divisions and eventually in new merged GS. One of the requests to the new merged GS, was to urge the GS in 2009 that whatever decision it took on this matter, to ensure that the unity of the churches was not compromised.

It took four conservative synodical meetings from Synod Midlands, not to mention the various CO. Art. 48 Deputy meetings (where deputies from the different Synods came together to discuss church-related matters) between these synodical meetings, where lots of differences have been ironed out, to discuss and finalise the merging of the three Synods, namely the Midlands, the GKSA and Soutpansberg. When congregations of the Synod of Midlands decided to meet, only congregations of the Synods GKSA and Midlands merged. Churches of Soutpansberg agreed not to merge, because they still held that such a merging could only be artificial unless extra conditions have been met before the merging took place. Since the democracy of 1994, little did we imagine that the GKSA would only begin to merge from 2009, 15 years later. This is not a positive message to the world from a church that had to lead in worshipping and sharing the bread across racial barriers!

Letšosa (2008) indicates that after the decision to merge has been taken, fear arose among members. Some viewed the 
decision as mere swallowing of the churches in Synod Midlands. The issues on the ground, congregational and cultural-specific activities, have not been addressed appropriately prior to the merging, and questions arose as to what practices should be continued or discontinued. It was not immediately clear what this merging would entail, because except for merging the synods and classes, many things remained the same. White people still worship on their own, and so do black people. Very few multi-racial or multi-cultural congregations exist. They all still have their own conferences and functions. In as much as there is no unity in the worship services, there is also less unity in the liturgy of life, which happens outside the Sunday worship services. Church conferences for youth and women are still held separately. We are aware of the Gereformeerde Teologiese Vereeniging/Reformed Theological Seminary (GTV/RTS), where all black and white ministers of the Word come together - which until recently, has English as the language of communication. We do notice, however, the few congregations that would walk the extra mile to work together with their neighbouring black congregation of the Reformed Church. Some partook in supporting the missionary work financially in the black congregations. Some participated actively in missionary work. Yet, we are also cognisant of Baloyi (2016)'s argument that those who support also control and have the final say (p. 2). I would, in this case, not like to generalise.

There is the possibility that this merging was merely artificial. Concerns did not only arise from some of the members of the Synod Midlands, but during the same year in March 2008, an open letter to the editor of the church journal, Die Kerkblad, was published: a member from the previously white congregations openly expressed his unhappiness with the unity of the churches of the GKSA and Synod Midlands, stipulating some reasons. According to him, the unity is part of the New Age movement - one nation, one language and one church. Another reason was that black members are more conservative regarding women in office, and this unity would be a step backward. Another fear that was expressed by him, was that the language in the new bigger, more expensive Synod would most probably be English, a step backward for Afrikaans. Another remark was that the white culture differs with that of the culture of black people. The last comment was that unity sits in Christ and not in the merging of churches. To this effect, the letter was replied to amicably and satisfactorily, from the author's perspective, although one cannot express oneself on how the response has been received. The point is that, in as much as there was excitement about the move forward, there were also questions among some members about the implications of this merging and the unity formed.

It is, however, sad that in 2018 a recent article appeared entitled: 'A continued racial character of some of the Gereformeerde Kerke in South Africa: Strategic moves evading reconciliation and unity of churches in postapartheid South Africa'. In this article, Baloyi (2018) addresses four main issues that have relevance to this study. The first argument relates to claims of achievement of reconciliation and unity, which is more artificial than real. This aspect is in line with Kujawa-Holbrook's third category of the compliant type, where the burden is placed on the marginalised group to make sure they assimilate and avoid conflict. The second aspect that Baloyi (2018) mentions, relates to the pretence of unity that is confusing. In this part, he mentions a few matters that are contrary to what unity signifies. In this matter, Kujawa-Holbrook would speak of the anti-racist congregation that has crossed racial barriers of white supremacy and racism. However, the institutional structures continue to maintain white privilege and white culture. In this regard, not much has changed regarding the agendas of synodical meetings. Most issues discussed, still relate to matters that have been previously on the agenda of the white congregations. Less issues pertaining to black congregations form part of these agendas.

The third aspect of Baloyi's article, concerns the continued use of Afrikaans as a weapon of racism. This has been an issue that keep occurring for still some time after the merging during Synodical meetings, in which Afrikaans has been used, and the rest of the non-Afrikaans speaking delegates had to use interpretation services. This happened more than once, until the matter had to be confronted. This was another sign that this was not an initiative that came from the side of the previously advantaged congregations. They still wanted to enjoy the privilege. Minutes and agenda are in English, but also in Afrikaans. It still appears that the rest of the other languages are just being accommodated. There is no sacrifice or compromise. The same is the case in attending church services where there are members of other races; they are welcome, yet they have their respective services in the same building. The opportunity is there to make the liturgy multi-language to accommodate everyone, as this would be the case with certain services on the Christian calendar.

The fourth part focuses on the dawn and mushrooming of multi-ethnic reformed churches in Tshwane. He argues that Reformed Churches with white congregants open their roofs to accommodate black people to conduct services in their buildings. He acknowledges that this is a step in the right direction, but Baloyi (2018) once more confirms Kujawa-Holbrook's third category of churches wherein conflict is avoided. The expectation is that those who come to join may do so, on the condition that they assimilate. In these congregations, they share facilities without sharing the power and ownership of the church. Baloyi (2018) holds that black members in these churches are convinced that black pastors are not wanted, although those who keep the status quo would be tolerated. One of the white members in an interview, indicated that concerning culture, tradition and ways of worship, average members regard worship in multi-cultural churches as non-reformed, inappropriate, with a lot of noise and unfamiliar to them. Baloyi (2018) also strongly argues that members use tradition and culture 
as excuses and a delaying tactic, instead of expediting unity after more than 20 years of democracy.

Questions can be asked in this regard - it is assumed that black congregations are growing - which is not necessarily the case in general. But if we take this as accurate, how do they grow and manage to secure buildings to conduct services if some white congregation churches are closing or being disbanded and buildings are sold? Looking through missional lenses, it should be considered how such facilities may be effectively used by fellow brothers and sisters. From which perspectives and according to whose views should decisions be made regarding the closing of such congregations? Through whose eyes and perspectives should decisions be reached regarding the closing of such congregations if people meet in Synodical meetings? Even though church councils can make independent decisions, classes and rings should look at such situations from a multiracial or cultural perspective and decide what is best for the church at large. An example is one of the buildings in Potchefstroom that has been sold, while a few black congregations have been without buildings for several years. It is lamentable to lose our beautiful buildings to other denominations, while fellow brothers must worship in the sun or travel and worship in farm areas passing buildings that are under-occupied because of liturgical restrictions.

\section{The role of liturgy as an anti-racism strategy}

Brown, Kaiser and Jackson (2013) also conducted a study on what we referred to in the article as a 'Liturgy of Life.' They studied the association between the exposure of members to race-based messages in places of worship and how they would engage white race-based policies in society. In their study it is found that the more white people were exposed to 'political congregations', the more critical they also become of 'racebased policies' in society. They (Brown et al. 2013) state:

This may suggest that when politically conscious clergy and lay members talk about race, they frame racial inequality as resulting from structural problems that require public policy solutions. Therefore, it seems that the form of an anti-racist liturgy would be to engage intentionally in 'racial discourse within worship spaces'. (p. 308)

However, their study also proves the opposite, as Brown et al. (2013) remark:

Houses of worship that avoid racial discussions may implicitly reinforce beliefs that racial inequality is unrelated to structural barriers to opportunity and, therefore, policies aimed at correcting such inequality are unwarranted. (pp. 308-309)

This fosters our hypothesis, that liturgy can play a role, should it consciously and intentionally be facilitated through the church's liturgy.

It is noteworthy in the outcome of Brown et al. (2013:308) that preaching about 'racism' is also a helpful anti-racist strategy as part of liturgy. Clergy and various theologians have illustrated this during apartheid South Africa, however, less in a post-apartheid context, to serve as an anti-racist strategy. For instance the sermon of Desmond Tutu during the funeral of the black consciousness leader, Steve Biko, in which he hails the cause of Biko as serving the purposes of God - when he fought for the collapse of the apartheid regime (cf. Allen 2006:15-21). His sermon was essentially 'political' on the day, because it focused on the relevance of the black consciousness movement towards racial liberation and the rejection of the racist policies of the apartheid government. Boesak's preaching on blackness and reformed identity during apartheid, serves as another example of 'anti-racism' preaching that reformed churches should adopt.

Van Schalkwyk (2002:77) also discusses the Eucharist as an element in the liturgy during the worship service, that provides the space for lamenting people's own stories and the 'wounds inflicted by the perpetrators of our apartheid past'. Further, she states that during the same Eucharist, Christians and participants could '... find a way into a future of healing and resurrection'. Van Schalkwyk (2002) further argues:

This eucharistic journey from pain to new life may be compared to the narrative therapeutic approach through which hurt people may remember their most traumatic experiences and heal these experiences by bringing them into the open in a compassionate and accepting environment. (p. 77).

The complexity with the latter proposal of Van Schalkwyk, however, is that not for all people their spaces of worship would be spaces of 'compassionate' and 'accepting' environments. However, while Van Schalkwyk's use of the Eucharist is aimed more at personal healing and restoration of people from the effects of racism, Kritzinger (2020:17) would engage the relevance of such an element of the liturgy (Eucharist) for breaking down racial walls, structures and systems, through the vision of a non-racial society by those participating and accepting the work of Christ through the cross and the resurrection. Here Kritzinger associates his arguments with that of Takatso Mofokeng, precisely his thesis, 'Christ among the crossbearers', where participation in the death of Christ through the Eucharist becomes a moment for Christians to accept that they should be in solidarity with those and the systems that keep those 'racial' crosses of suffering in place. It is the same Christ whose 'wounds' were also inflicted by a system of imperial oppression and rule. It is to that system that those participating in the Eucharist are called to oppose'. Nevertheless, Van Schalkwyk (2002:79) agrees that the Eucharist also helps people during the liturgy to 'go further in our resistance against oppression and justice' and to 'move into a new phase of liberation and transformation' that would imply that participants would come to understand justice as the restoration of relationships 'between people with all the material and spiritual consequences that such a project of restoration holds for especially the marginalised, 
the poor, and the severely wounded in society' (Van Schalkwyk 2002:79).

Perhaps a final illustration of introducing an anti-racism praxis within the liturgy, is what Kritzinger (2020:17) suggests could be done during the Eucharists of Reformed Churches. He underscores that while the controversy in history about the Eucharist was mainly about the 'real presence' of Jesus at the table, an anti-racist strategy would be to do more to: 'lift up our hearts at the table to our heavenly High Priest ... and to ... not practice escapism by taking our eyes off our own suffering or the suffering of those through whom he is present among us: those whom he is not ashamed to call his 'brother and sister' (Heb 2:11)' But then he mentions an interesting symbolic gesture during the Eucharist at his own congregation, which seems to foster the social imagination needed to change structural racism in society. There is an empty chair at the communion table at the URCSA Congregation in Tshwane during the Eucharist. He (Kritzinger 2020) mentions that the liturgist would often use expressions such as:

God sends us from this Table to go and make all the tables we will sit at in the coming week just like this one: tables of equality, inclusion, justice and joy. (p. 18)

Then he argues that this kind of eucharistic praxis has the potential to transform the lives of individuals who are troubled and oppressed by racism or another negative ideology. Still, it also has the potential to have a broader, more structural impact (Kritzinger 2020:19). However, he also suggests, among others, that the empty chair could also be used to remind us constantly of the fact that within and without church structures, and in this moment, the liturgist could remind the congregation saying something like: 'It is not about all of us who are here today; God sends us from this table to care of those who are not here'. Kritzinger (2020) suggests further that the liturgist could also:

... invites members to 'place' on the chair anyone they are missing - and to 'welcome' them at the table, and the liturgist could use this opportunity to emphasise the inclusiveness of the Table. (p. 19)

Finally, another question relates to the development of a familiar liturgy that could be welcoming, not only to members from other races in the reformed tradition but also to outsiders. Cilliers (2010:344) proposes a liturgy of (or: in) transition. The problems that have been there over the past years when he wrote his article are still as fresh as ever, if not even more appropriate, especially now that the COVID-19 pandemic has taken so many lives. South Africa is still in a liminal space - which calls for rethinking worship. Much has been written about worship, but less has been put into place in the reformed tradition. What Cilliers strongly argues against, is a modernised liturgy following a fashionable trend. Liminality should be seen as being en route: having left but still to arrive. The Reformed Churches in South Africa have taken a step forward in the right direction, and there is no question about it. However, the journey is swirling in transit. Kunin (1989) as quoted by Cilliers (2010:344), shows a way forward to how this transition could be approached:

Characteristically the liminal phase is constituted by the convergence or interweaving of qualities of both categories between which it is sandwiched: 'Since the liminal is neither fully one type of space (category) nor the other, it will take on aspects of both; it is this indeterminacy of quality and therefore predictability that creates the aspect of danger'. (p. 30)

Space should be created where the various liturgies are merged into a common reformed liturgy, so that the different cultures and races can relate to each other, as we are all in transit. Cilliers points out that liminality makes people think alike because they are on the same journey. The authors would suggest a process of transition with arrival still suspended to be able to reflect, and through worshipping together, come with ultimate meanings and interpretations of reality. In this liminality there is space for dying and living, hope and resurrection. In such a liturgy, there is hope for new revelation and transformation. Cilliers (2013:346) suggests a language of lament and not psychological or religious self-pity, but lamenting in liminality where one can no longer hide or mask behind or be disguised by secure structures. Instead, such structures should be brought to light, and in essence beat against the heart of God. It is within created liturgical spaces where various races worship together, where we can beat against the heart of God in lamentation, where the walls of liturgical separation have fallen. It is in anticipation of the coming that we can complete the journey and cross these barriers of liturgical separation, influenced by the systemic hidden racism that secures one's own identity to the disadvantage and disregard of the other.

\section{Conclusion}

In Jeremiah 6:14, the Lord cries out that the wounds of his people have been treated carelessly, saying 'peace, peace', while there is no peace. This article shows that although much has been done in the Reformed Churches to address racism, there is still a long road to be travelled by the Reformed Churches in South Africa. The authors argued that the reformed liturgy could assist as an anti-racism action, to allow churches to move towards non-racial churches, not only in principle and in its policies, but also in practice. This is possible through journeying together across barriers of separation, looking for answers together and lamenting together. Unity in structure could find fulfilment in worshipping together across cultural differences.

\section{Acknowledgements Competing interests}

The authors declared that no competing interest exists.

\section{Authors' contributions}

E.B. and R.L. contributed equally to this work. 


\section{Ethical considerations}

This article followed all ethical standards for research without direct contact with human or animal subjects.

\section{Funding information}

This research received no specific grant from any funding agency in the public, commercial or not-for-profit sectors.

\section{Data availability}

The authors confirm that the data supporting the findings of this study are available within the article.

\section{Disclaimer}

The views and opinions expressed in this article are those of the authors, and do not necessarily reflect the official policy or position of any affiliated agency of the authors.

\section{References}

Allen, J. (ed.), 2006, Desmond Tutu- - The rainbow people of God: A spiritual journey from apartheid to freedom, Double Storey, Cape Town.

Baloyi, E.M., 2016, 'Unpacking the downside of sustentasie on African theology and theologians: A need for contextual black theology as a liberatve ingredient for the black Reformed churches', HTS Theological Studies 72(1), 1-8. https://doi. org/10.4102/hts.v72i1.3161

Baloyi, E.M., 2018, 'A continued racial character of some of the Gereformeerde Kerke in South Africa: Strategic moves evading reconciliation and unity of churches in post-apartheid South Africa', HTS Theological Studies 74(1), 1-8. https://doi. org/10.4102/hts.v74i1.4782

Banton, M., 1998, Racial theories, 2nd edn., Cambridge University Press, Cambridge.

Baron, E., 2019, 'The call for African missional consciousness through renewed mission praxis in URCSA', Studia Historiae Ecclesiastiae 45(3), 1-19. https://doi. org/10.25159/2412-4265/6184

Baron, E., 2020, Die Ligdraer as a Grassroots Engagement of URCSA's church unification and reconciliation between 1990-1997', Missionalia 48(1), 81-100. https://doi.org/10.7832/48-1-383

Baron, E. \& Botha, N.A., 2020, Obedience and servant leadership: Appollis, appies, buti, buys, Sun Media, Bloemfontein.
Baron, E. \& Maponya, M.S., 2020, The recovery of the prophetic voice of the church: The adoption of a missional church imagination', Verbum et Ecclesia 41(1), 1-9. https://doi.org/10.4102/ve.v41i1.2077

Becerra, S.E., 2016, 'Worship and the magisterial reformers', in A.M. Rodríguez (ed.), Worship, ministry, and the authority of the church: Studies in Adventist Ecclesiology, p. 3, Biblical Research Institute, Silver Spring, MD.

Brown, R.K., Kaiser, A. \& Jackson, J.S., 2013, 'Worship discourse and white race-based policy attitudes', Review of Religious Reearchs 56, 291-312. https://doi. org/10.1007/s13644-013-0139-9

Bulmer, M. \& Solomon, J., 1999, Racism, Oxford University Press, Oxford.

Carter, J.K., 2008, Race: A theological account, Oxford University Press, Oxford.

Carter, J.K., 2010, Race: A theological account, Oxford University Press, Oxford.

Cilliers, J., 2010, 'The liminality of liturgy', Scriptura 104, 343-351. https://doi. org/10.7833/104-0-175

Jennings, W.J., 2010, The Christian imagination: Theology and the origins of race, Yale University Press, New Haven, CT.

Kritzinger, J.N.J., 2020a, The Eucharist in anti-racist praxis, SAMS virtual conference.

Kritzinger, J.N.J., 2020b, The Eucharist in anti-racist praxis, Presented at SAMS virtual conference.

Kujawa-Holbrook, S.A., 2006, 'Racism and anti-racism in congregations', in S. KujawaHolbrook (ed.), Seeing God in each other, pp. 48-57, Morehouse, Harrisburg, PA.

Letšosa, R.S., 2008, 'Hoe staan sake tans met die twee Sinodes wat een geword het? Brandpunt', Die Kerkblad, Junie, pp. 10-11.

Loubser, J.A., 1987, The Apartheid Bible: A critical review of racial theology in South Africa, Maskew Miller Longman, Cape Town.

Nel, B.P., 2019, 'To build a new church together? Exploring Interdisciplinary dialogue with a Christian women's ministry: Addressing patriarchy in URCSA', Studia Historiae Ecclesiastiae 45(3), 1-15. https://doi.org/10.25159/2412-4265/6234

Plaatjies Van Huffel, M.A., 2019, 'A history of gender insensitivity in URCSA', Studia Historiae Ecclesiastiae 45(3), 1-22. https://doi.org/10.25159/2412-4265/6250

Spangenberg, I.J.J., 2019, 'The religious roots of racism in the Western world: A brief historical overview', HTS Theological Studies 75(1), a5187. https://doi. org/10.4102/hts.v75i1.5187

Strickland, W.R. (II), 2020, Biblical Principles for Diversity and Reconciliation in Ministry (PC255), Lexham Press, Bellingham, WA.

Tshaka, R.S. \& Maruping, P., 2010, 'The hastening that waits?: A critical assessment of the tangibility of unity within the Uniting Reformed Church in Southern Africa', Verbum et Ecclesia 31(1), 1-4. https://doi.org/10.4102/ve.v31i1.426

Uniting Reformed Church of Southern Africa (URCSA), 1997, Submission of the Uniting Reformed Church in Southern Africa to the Truth and Reconciliation Commission, TRC Archives, Cape Town. (The submission is also available at the Beyers Naudé Centre, University of Stellenbosch.)

Van der Meulen, T., 2008,' Gaan dit regtig so goed daar?' Kerkblad, 5 Maart, p. 49.

Van Schalkwyk, A., 2002, 'On stigma, racism and reconciliation in a post-apartheid South Africa', Missionalia 30(1), 70-81.

Young, C., 1994, The African colonial state in comparative perspective, Yale University Press, New Haven, CT. 